\title{
Diversity of Arbuscular Mycorrhizal Fungi in an Amazon Environment after Mining
}

\author{
Ana Lucy Caproni ${ }^{1}$, Jose Rodolfo Dantas de Oliveira Granha ${ }^{1}$, \\ Ademir Junior Fornaciari², Camila Pinheiro Nobre ${ }^{3}$, Leticia Pastore Mendonça ${ }^{2}$, \\ Ricardo Luiz Louro Berbara ${ }^{2}$ \\ ${ }^{1}$ Fundação Universidade de Rondônia - UNIR, Campus de Guajará-Mirim, Guajará-Mirim/RO, Brasil \\ ${ }^{2}$ Departamento de Solos, Universidade Federal Rural do Rio de Janeiro - UFRRJ, Seropédica/RJ, Brasil \\ ${ }^{3}$ Universidade Estadual do Maranhão - UEMA, São Luís/MA, Brasil
}

\begin{abstract}
At the Brazilian Amazon forest, studies were carried out to estimate the community of arbuscular mycorrhizal fungi (AMF), from this it was used a bioassay of dilutions of samples collected from preserved and regenerated areas after bauxite extraction. To regenerate areas, tree species were introduced and samples were taken after 2, 6, 12, and 16 years, the spores obtained were compared to those obtained by direct extraction and the number of species recovered from the bioassay was significantly higher. Therefore, the species founded after different periods regeneration was similar to the ones from the native forest. Since the early years of revegetation, the number of rare species was high with strong dominance of G. macrocarpum. Among older communities this high dominance decreased while at the same time, there was an increase in the number of individuals from other AMF species, concluding that the number of species did not change with the age of the revegetation.
\end{abstract}

Keywords: glomeromycota, diversity, bioassay. 


\section{INTRODUCTION}

Bauxite mining in the Brazilian Amazon represents an important economic activity that involves the removal of the entire plant cover and also the soil layer (Caproni et al., 2003). The negative impact of mining in soil organisms and in soil function is visible (Melloni et al., 2003), causing reduction in diversity and density of arbuscular mycorrhizal fungi (AMF) (Mergulhão et al., 2010).

AMF are an important group of soil organisms forming symbioses with, at least, $74 \%$ of all plant species (Smith \& Read, 2008; Brundrett, 2009; van der Heijden et al., 2015). In this relationship the fungus receives carbon from plant and in exchange gives to the host mineral nutrients that improve the tolerance to biotic and abiotic effects (Smith \& Read, 2008). The symbioses also influence plants interactions and the plant communities structure, affecting agricultural production and the ecosystems conservation and restoration (van der Heijden et al., 2008).

The principal strategy of recuperation of these mining areas is the reintroduction of the organic superficial layer with organic matter (Caproni et al., 2003) and revegetation with native plant species. The success of the revegetation process depends on the knowledge of plants capacity to form mycorrhizal symbiosis (Jasper et al., 1991) and the use of plant species with high dependency of AMF can improve the revegetation of mining areas (Sousa et al., 2014). Hence, the results of these improvements during the initial phases of succession can help soil to be more adequate for plants establishment in later phases of the succession (Zangaro et al., 2000; Sousa et al., 2014).

The AMF composition and communities richness is based on the spores morphology because most of the species are described using the morphological information (Landis et al., 2004). Nevertheless, the morphological identification of spores from field can be problematic due to the degradation state of the spores (Turrini et al., 2010). Thus for solve this problem a bioassay can then be recommended for a better estimate of the number of species present in soil (Tommerup, 1994; Hendrix et al., 1995). This technique is based on the identification of spores of species that have multiplied in different dilutions (Hendrix et al., 1995). However, the disadvantage of this method is detecting only species that are producing spores (Brundrett et al., 1999), together with the identification of spores extracted directly from soil the bioassay method can access almost the complete diversity of AMF in an area.

The objective of the present study is to estimate changes in the structure and diversity of AMF in soil samples collected from the Amazon primary forest and in degraded areas due to bauxite extraction after different time of revegetation.

\section{MATERIAL AND METHODS}

\subsection{Sampling}

To assess the occurrence AMF species, soil samples were collected from degraded areas due to bauxite mining and with native species revegetation. Samples were taken after 2, 6, 12, 16 years of revegetation in the wet season (April 1999) in Porto Trombetas, State of Pará, Brazil. The top soil previously removed was returned at the establishment of the seedlings.

Four samples from of 10 subsamples each were randomly collected from an area of approximately $100 \mathrm{~m}^{2}$ inside each sampled area. The subsamples were collected from $0-20 \mathrm{~cm}$ depth, at no defined distance from the tree trunk where the vegetation was dense as well as from the root zone of trees where the vegetation was sparser.

One part of the soil samples was used for spore extraction, counting, and identification and the other part was used to set up the bioassay experiment as discussed by Hendrix et al. (1995).

\subsection{Spore recovery and identification}

The spores were extracted of $100 \mathrm{~mL}$ of each tyoe of sample using the humid sifting technique (Gerdemann \& Nicolson, 1963) then centrifuged in a sucrose solution (Daniels \& Skipper, 1982). After extraction, the spores were grouped according to characteristics of size, color and shape. The groups were placed on slides with polyvinyl alcohol in lactoglycerol (PVLG). The spores were gently crushed under a cover slip to expose their inner walls, on the same slides, a second spore group was set up with PVLG + Melzer reagent (1:1) under another cover slip. A color reaction to the Melzer reagent was used to identify the wall 
characteristics, especially in the cases of spores with adherent or very fine walls.

AMF species were identified by the method of Schenck \& Perez (1988), based on the morphological descriptions available on the Internet on the International Culture Collection of Arbuscular Mycorrhizal Fungi page (INVAM, 2000), and new species publications. The taxonomic characteristics were interpreted by light microscopy observations with light-field illumination and with an immersion objective, made it possible by the classification adopted, proposed by Oehl et al. (2011), including additional taxa proposed by Błaszkowski (2012) and Goto et al. (2012).

\subsection{Bioassay}

To estimate the diversity of AMF and the number of infective propagules (IP) per species, a bioassay was set up for each of the 5 areas under study using the protocol described by Sieverding et al. (1991), with some modifications described below.

Eight base 4 serial dilution levels were used in each bioassay. The first level $\left(4^{\circ}\right)$ consisted of the test soil without dilution, for level $4^{-1}, 750 \mathrm{~mL}$ of autoclaved soil material (free of AMF) was mixed in a plastic bag with $250 \mathrm{~mL}$ of the inoculum soil, it was vigorously homogenized with approximately 100 shakes. For $4^{-2}$, $250 \mathrm{~mL}$ of the $4^{-1}$ dilution was mixed with $750 \mathrm{~mL}$ of the autoclaved soil material, the process was repeated successively up to the $4^{-7}$ dilution. The material of each dilution was divided into 5 replicates by placing $250 \mathrm{~mL}$ of the diluted material in the lower half of 5 plastic tubes with $250 \mathrm{~mL}$ capacity and the upper half completed with sterilized soil material to avoid contamination. The tubes were placed in plastic supports, which in turn were placed on tables in a greenhouse. Each table had 40 tubes per support (8 dilutions $\mathrm{x} 5$ replicates).

The bioassay was kept in the greenhouse for 6 months in order to allow the maximum production of spores and not only colonization. At the greater dilution, at least one replica containing spores of some species was found, implying that either the number of dilutions was not enough for extinction or, despite the precautions, some contamination might have occurred. The trap plant used was Brachiaria decumbens, which is mycotrophic for most AMF species (Simpson \& Daft, 1990). Thus five seeds per tube were used for sowing, thirty days after emergence, the seedlings were thinned by cutting close to the surface of the substrate, and the only plant per tube was left. For this reason, a new randomization of the trays with the tubes was performed on the tables at 30 day intervals in order to avoid a position effect (location, light and temperature).

The plantings were carefully irrigated with sterilized water (boiled, then cooled) whenever necessary. Six months after the beginning of the experiment, irrigation was stopped and the plants were left to dry up. The aerial part was discarded, the substrate was homogenized, and a sample was taken from each tube for spore extraction and species identification. The presence or absence ( + or -) of spores was estimated at each dilution level (Hendrix et al., 1995).

\subsection{Statistical analysis}

The number of species recovered by the bioassay was compared to the number of species collected directly from the field by the Mann-Whitney test at $5 \%$. Standard error of the mean was applied to the number of spores recovered from soil samples collected from the field and from the bioassay.

The species richness and diversity indices of Shanonn-Wiener, the dominance index of Simpson and the equitability index of Pielou for AMF species were calculated for community analysis (Hendrix et al., 1995) in each area studied.

Species richness was evaluated as the ratio between the number of species observed and sample size in $100 \mathrm{~mL}$ of soil.

The diversity index of Shannon-Wiener $\left(\mathrm{H}^{\prime}\right)$ was calculated for each sample according to the Formula 1:

$\mathrm{H}^{\prime}=-\mathrm{S}\left(\mathrm{X}_{\mathrm{i}} / \mathrm{X}_{\mathrm{o}}\right) \cdot \log \left(\mathrm{X}_{\mathrm{i}} / \mathrm{X}_{\mathrm{o}}\right)$

where: $X_{i}=$ density of spores of each species in $100 \mathrm{~mL}$ of soil.

$\mathrm{X}_{\mathrm{o}}=$ total density of spores of all species

The dominance index of Simpson (C) was calculated by the Formula 2:

$\mathrm{C}=\Sigma\left(\mathrm{X}_{\mathrm{i}} / \mathrm{X}_{\mathrm{o}}\right)^{2}$

And the equitability index of Pielou (J') was calculated by the Formula 3:

$\mathrm{J}^{\prime}=\mathrm{H}^{\prime} / \log \mathrm{S}$

where: $\mathrm{S}=$ total number of AMF species in $100 \mathrm{~mL}$ of soil. 


\section{RESULTS}

\subsection{AMF diversity}

Diversity and structure of AMF communities were surveyed either directly on spores isolated from the field soil or on spores isolated from bioassay. The richness of AMF species recovered by the MPN bioassay (Figures 1 and 2$)$ was significantly greater $(\mathrm{P}=0.05$ by

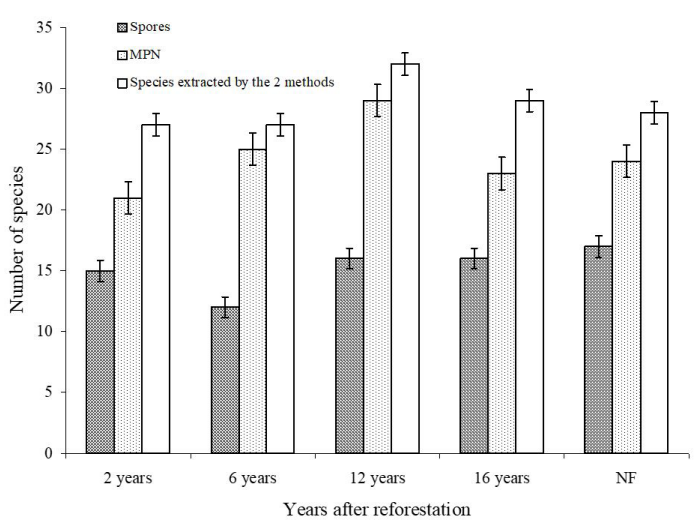

Figure 1. Number of AMF species recovered after MPN and by direct counting of samplings from reforested areas left after bauxite mining in Porto Trombetas - Pará, Brazil after 2, 6 and 12 years of reforestation; in reforested areas without the addition of organic matter 16 years after reforestation, and from a native forest. the Mann-Whitney test). The bioassay provided a better estimative of the richness of AMF, compared to that obtained by the sum of the both techniques.

The diversity indices were different when estimated by counting spores recovered by the direct counting technique from soil samples in the field or by the bioassay (Figure $2 \mathrm{a}$ and $2 \mathrm{~b}$, respectively). The technique used to find the number of spores directly extracted from the field yielded more variation than the bioassay as shown by the dominance index of Simpson (Figure 2a). The Pieolou and Shannon table of contents also yielded the same results.

Consequentely, this wide variation in the results obtained by direct extraction of spores from the field, suggests that this method, separately, may be inadequate to determine AMF diversity.

The diversity index of Shannon, estimated by using the bioassay values, (Figure 2b) was very low for the 2 and 6-year-old areas due to the high dominance of the species G. macrocarpum (Table 1), as also shown by the high value of the Simpson index.

\subsection{Comparison of the populations recovered between the bioassay and the by spore collection in the field}

From the 21 species found at the 2-year-old revegetated site, only G. macrocarpum was responsible for the high dominance while species dominance

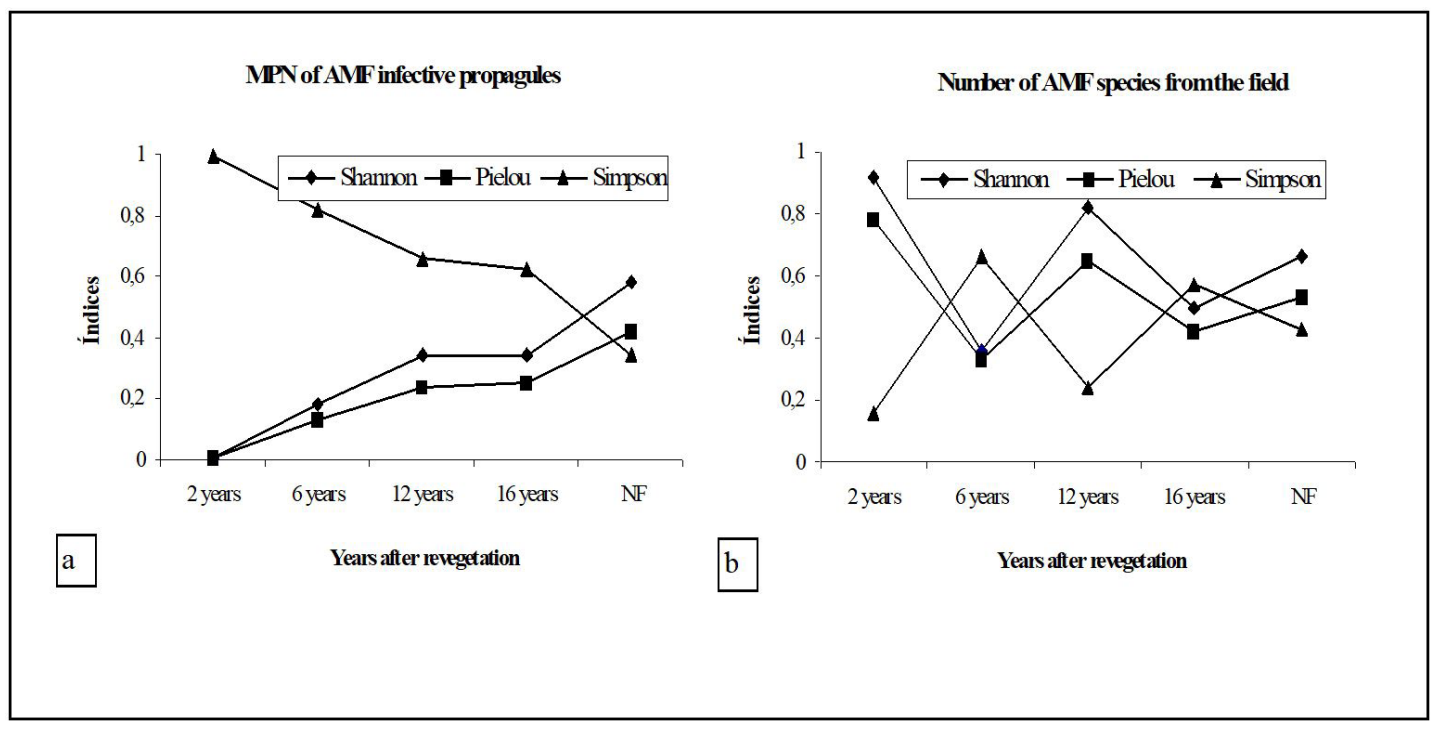

Figure 2. Diversity indices of the AMF species calculated from the propagules recovered by the MPN technique (a) and by the direct extraction from soil samples collected in the field (b), in areas left after bauxite mining and revegetated 2, 6, 12 and 16 years before, and from a primary forest (PF) in Porto Trombetas, PA. 
decreased with the succession sequence although the total number of species was similar.

The Table 2 consist in lists of the species recovered from the bioassay and the number of spores of recovered species of the genus Acaulospora and Ambispora. Ten species of the genus Acaulospora and 1 of the genus Ambispora were isolated, with A. denticulata and Acaulospora sp2 not being detected by the technique of direct spore extraction (DS) from field soil and with Acaulospora sp1 not being detected by the bioassay. A. foveata, A. leptoticha and A. tuberculata were detected by this technique in all revegetated areas, thus as a whole, the two techniques permitted the recovery of 10 Acaulospora species and 1 Ambispora species.

In the second year of revegetation, Acaulospora genus had greater diversity and number of spores than in the subsequent years or in the native forest. The bioassay values were uniform in all areas except for A. mellea which presented greater variation in the 16-year-old area. In this area, A. mellea had a larger number of infective propagules than spore density. For Acaulospora, the estimated number of species isolated from the bioassay was usually much lower than the number of spores extracted directly from soil.

The technique of direct spore extraction permitted the detection of only the specie Kuklospora colombiana in the 6-year-old revegetated area (Table 3). However, using the bioassay technique, propagules of this species were detected in all the areas under study. Two unidentified species of genus Entrophospora were also found in the studies areas (Entrophospora sp1 in 6- and 16-year-old areas, and Entrophospora sp5 in 6-, 12- and 16-year-old areas and in the primary forest).

The Table 4 shows the density of genus from Gigasporales. The species of the genus Gigaspora was also found in a greater number after the bioassay

Table 1. Spores of Glomerales and Paraglomerales species determined by MPN infective number of propagules method and spore density (SD) in $100 \mathrm{~mL}$ of soil sample collected from reforested areas left after bauxite mining after 2, 6 and 12 years of reforestation and under native forest (NF).

\begin{tabular}{|c|c|c|c|c|c|c|c|c|c|c|}
\hline \multirow{2}{*}{ Espécies } & MPN & SD & MPN & SD & MPN & SD & MPN & SD & MPN & SD \\
\hline & \multicolumn{2}{|c|}{--2 years-- } & \multicolumn{2}{|c|}{--6 years-- } & \multicolumn{2}{|c|}{---12 years--- } & \multicolumn{2}{|c|}{---16 years--- } & \multicolumn{2}{|c|}{----NF---- } \\
\hline Claroideoglomus & 9.1 & 485 & - & - & - & - & 0.2 & - & 0.2 & 2 \\
\hline Cl. etunicatum & 0.2 & - & 1333 & 57 & 255 & 25 & 2691 & 342 & 600 & 24 \\
\hline Funneliformis geosporum & - & - & 111 & 9 & 63 & - & 252 & - & 793 & 19 \\
\hline G. caledonium & 16 & 16 & - & - & - & - & - & - & - & - \\
\hline G. clavisporum & - & - & - & - & - & 94 & - & - & - & - \\
\hline G. diaphanum & 0.2 & - & - & - & 0.2 & - & - & - & - & - \\
\hline G. formosanum & - & 16 & 0.7 & 35 & 48 & 185 & 3 & 12 & 6.9 & 17 \\
\hline G. glomerulatum & - & - & 447 & - & 1.3 & - & 447 & 92 & 793 & - \\
\hline G. macrocarpum & 13962 & 521 & 18425 & 2819 & 4951 & 1710 & 13963 & 5339 & 4951 & 503 \\
\hline G. magnicaule & - & - & - & 9 & - & - & - & - & - & 4 \\
\hline G. microcarpum & 36 & - & - & - & 0.5 & 32 & - & 12 & - & - \\
\hline G. nanolumem & - & - & 0.2 & - & 2.3 & 637 & - & 170 & 0.5 & 8 \\
\hline G. reticulatum & - & - & 1.7 & - & 600.9 & 841 & 0.7 & 181 & 2691.0 & 16 \\
\hline G. sp1 & - & - & - & 180 & - & - & - & 235 & - & 56 \\
\hline G. sp2 & - & - & - & - & - & 70 & - & 110 & - & 39 \\
\hline G. sp4 & - & - & 1.7 & - & 0.2 & - & - & - & 0.2 & - \\
\hline G. sp5 & - & - & - & - & - & - & - & 36 & - & - \\
\hline G. sp6 & - & - & 6.9 & - & - & - & 0.7 & 42 & 0.5 & 26 \\
\hline G. sp7 & - & - & 9.1 & 7 & 191.5 & 250 & 2.3 & - & 27.5 & - \\
\hline Paraglomus occultum & 0.2 & - & 0.5 & - & 0.2 & - & 1.3 & - & - & - \\
\hline Rhizoglomus clarum & 0.2 & - & - & - & - & - & - & - & - & - \\
\hline Rhi. intrarradices & 0.2 & - & 0.2 & - & - & - & - & - & - & - \\
\hline Rhi. invernaium & - & - & - & - & 0.6 & - & - & - & 1.0 & - \\
\hline Sclerocystis sinuosum & - & - & - & - & - & 61 & - & - & - & - \\
\hline
\end{tabular}


Table 2. Spores of Acaulospora and Ambispora species determined by MPN infective number of propagules method and spore density (SD) in 100 mLof soil sample collected from reforested areas left after bauxite mining after 2, 6 and 12 years of reforestation and under native forest (NF).

\begin{tabular}{|c|c|c|c|c|c|c|c|c|c|c|}
\hline \multirow{2}{*}{ Espécies } & MPN & SD & MPN & SD & MPN & SD & MPN & SD & MPN & SD \\
\hline & \multicolumn{2}{|c|}{--2 years-- } & \multicolumn{2}{|c|}{--6 years-- } & \multicolumn{2}{|c|}{---12 years--- } & \multicolumn{2}{|c|}{---16 years--- } & \multicolumn{2}{|c|}{----NF---- } \\
\hline A. denticulata & 0.4 & - & - & - & - & - & - & - & - & - \\
\hline A. foveata & 3.0 & 283 & 0.2 & - & 0.2 & 89 & 0.7 & - & 0.4 & 20 \\
\hline A. mellea & 3.0 & 87 & 6.9 & 118 & 20.9 & 39 & 600.9 & 120 & - & 13 \\
\hline A. morrowiae & - & 84 & 1.0 & 22 & 0.2 & - & 9.1 & 12 & 0.2 & - \\
\hline A. rehmi & 0.7 & 69 & 0.5 & - & - & - & - & - & - & - \\
\hline A. scrobiculata & 0.4 & 24 & - & - & 0.2 & - & - & - & 0.2 & - \\
\hline A. $\mathrm{sp} 1$ & - & - & - & - & - & - & - & 65 & - & - \\
\hline A. $\mathrm{sp} 2$ & 0.2 & - & - & - & - & - & - & - & - & - \\
\hline A. spinosa & - & 8 & - & - & 0.2 & - & - & - & - & - \\
\hline A. tuberculata & 1.3 & 160 & 0.2 & - & 1.3 & 67 & 6.9 & 330 & 1.7 & - \\
\hline Am. leptoticha & 1.3 & 112 & 36.3 & - & 0.7 & 17 & 12.0 & - & 47.9 & 4 \\
\hline
\end{tabular}

Table 3. Spores of Kuklospora and Entrophospora species determined by MPN infective number of propagules method and spore density (SD) in $100 \mathrm{~mL}$ of soil sample collected from reforested areas left after bauxite mining after 2, 6 and 12 years of reforestation and under native forest (NF).

\begin{tabular}{|c|c|c|c|c|c|c|c|c|c|c|}
\hline \multirow{2}{*}{ Espécies } & MPN & SD & MPN & SD & MPN & SD & MPN & SD & MPN & SD \\
\hline & \multicolumn{2}{|c|}{--2 years-- } & \multicolumn{2}{|c|}{--6 years-- } & \multicolumn{2}{|c|}{---12 years--- } & \multicolumn{2}{|c|}{---16 years--- } & \multicolumn{2}{|c|}{----NF---- } \\
\hline Kuklospora colombiana & 0.4 & - & 0.2 & 9.0 & 0.7 & - & 15.8 & - & 0.5 & - \\
\hline Entrophospora sp1 & - & - & 1.3 & - & - & - & 0.2 & - & - & - \\
\hline E. sp5 & - & - & 1.7 & - & 1.3 & - & 36.3 & - & 1.3 & - \\
\hline
\end{tabular}

(Table 3). Spores of G. margarita were recovered from areas that had been revegetated 6 and 12 years before and from the primary forest. Using the bioassay technique, propagules of G. gigantea were found in the 12 -year-old area and in the primary forest. By direct extraction, G. gigantea spores were recovered only from soil samples obtained from the primary forest. Two more species (Gigaspora sp1 and Gigaspora sp2) were recovered by this method in 2-, 12- and 16-year-old areas and in the primary forest, with a total of 4 species of the genus Gigaspora being recovered.

Scutellospora calospora was detected by bioassay and direct counting in 6-, 12- and 16-year-old revegetated areas. Fuscutata heterogama was recovered from 16-year-old areas and from the primary forest, but only from the primary forest when direct counts were used. Scutellospora sp. 1 was recovered from areas aged 2, 6, 12 and 16 years by the bioassay technique for biassay determination, and from a 2-year-old area only by direct count. Racocetra weresubiae was recovered only from the 2 -year-old area by both techniques and
Scutellospora sp2 was only recovered from 2-years-old area by direct count.

Considering the number of propagules of Gigasporales species, it can be seen that in all cases the bioassay estimate, was lower than spore density determined by the technique of direct field extraction. The same occurred with the genus Acaulospora.

The Table 5 shows the infective propagules number and the spore density of Glomerales and Paraglomerales species. The both methods allowed the recovery of 24 species of these orders. Six species were only found in the bioassay (Glomus diaphanum, Glomus sp4, Rhizoglomus clarum, Rhi. intraradices, Rhi. Invernaium and Paraglomus occultum). By direct extraction we recovered 6 additional species that were not recovered by the bioassay (G. clavisporum, G. magnicaule, G. sp1, G. sp2, G. sp5).

Glomus macrocarpum had a higher density spores than the remaining species present in all recovering areas, including the primary forest. The lowest density of infective propagules of G. macrocarpum occurred in an area revegetated 12 years before and in the primary forest. 
Table 4. Spores of Gigasporales species determined by MPN infective number of propagules method and spore density (SD) in $100 \mathrm{~mL}$ of soil sample collected from reforested areas left after bauxite mining after 2, 6 and 12 years of reforestation and under native forest (NF).

\begin{tabular}{|c|c|c|c|c|c|c|c|c|c|c|}
\hline \multirow{2}{*}{ Espécies } & MPN & SD & MPN & SD & MPN & SD & MPN & SD & MPN & SD \\
\hline & \multicolumn{2}{|c|}{--2 years-- } & \multicolumn{2}{|c|}{--6 years-- } & \multicolumn{2}{|c|}{ 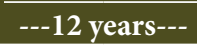 } & \multicolumn{2}{|c|}{---16 years--- } & \multicolumn{2}{|c|}{----NF---- } \\
\hline Fuscutata heterogama & - & - & - & - & - & - & 0.2 & - & 0.2 & 2 \\
\hline Gigaspora gigantea & - & - & - & - & 0.2 & - & - & - & 0.2 & 2 \\
\hline Gi. margarita & - & - & 0.2 & 14 & 0.2 & 17 & - & - & 0.2 & 3 \\
\hline Gi. sp1 & - & - & - & - & 6.9 & - & 0.2 & - & - & - \\
\hline Gi. $\mathrm{sp} 2$ & 0.2 & - & - & - & 0.2 & - & - & - & 0.2 & - \\
\hline Racocetra weresubiae & 0.4 & 51 & - & - & - & - & - & - & - & - \\
\hline Scutellospora calospora & - & - & 6.9 & 218 & 0.2 & 5 & 0.2 & 36 & - & - \\
\hline Scutellospora sp. & 0.2 & - & 0.2 & - & 0.2 & - & 0.2 & - & - & - \\
\hline Scutellospora sp1. & - & 87 & - & - & - & - & - & - & - & - \\
\hline
\end{tabular}

Table 5. Spores of Glomus and Paraglomus species determined by MPN infective number of propagules method and spore density (SD) in $100 \mathrm{~mL}$ of soil sample collected from reforested areas left after bauxite mining after 2, 6 and 12 years of reforestation and under native forest (NF).

\begin{tabular}{|c|c|c|c|c|c|c|c|c|c|c|}
\hline \multirow{2}{*}{ Espécies } & MPN & SD & MPN & SD & MPN & SD & MPN & SD & MPN & SD \\
\hline & \multicolumn{2}{|c|}{--2 years-- } & \multicolumn{2}{|c|}{--6 years-- } & \multicolumn{2}{|c|}{---12 years--- } & \multicolumn{2}{|c|}{---16 years--- } & \multicolumn{2}{|c|}{----NF---- } \\
\hline G. caledonium & 16 & 16 & - & - & - & - & - & - & - & - \\
\hline Claroideoglomus claroideum & 9.1 & 485 & - & - & - & - & 0.2 & - & 0.2 & 2 \\
\hline G. clarum & 0.2 & - & - & - & - & - & - & - & - & - \\
\hline G. clavisporum & - & - & - & - & - & 94 & - & - & - & - \\
\hline G. diaphanum & 0.2 & - & - & - & 0.2 & - & - & - & - & - \\
\hline G. etunicatum & 0.2 & - & 1333 & 57 & 255 & 25 & 2691 & 342 & 600 & 24 \\
\hline G. formosanum & - & 16 & 0.7 & 35 & 48 & 185 & 3 & 12 & 6.9 & 17 \\
\hline G. geosporum & - & - & 111 & 9 & 63 & - & 252 & - & 793 & 19 \\
\hline G. glomerulatum & - & - & 447 & - & 1.3 & - & 447 & - & 793 & - \\
\hline G. glomerulatum & - & - & - & - & - & - & - & 92 & - & - \\
\hline G. intrarradices & 0.2 & - & 0.2 & - & - & - & - & - & - & - \\
\hline G. invernaium & - & - & - & - & 0.6 & - & - & - & 1.0 & - \\
\hline G. macrocarpum & 13962 & 521 & 18425 & 2819 & 4951 & 1710 & 13963 & 5339 & 4951 & 503 \\
\hline G. magnicaule & - & - & - & 9 & - & - & - & - & - & 4 \\
\hline G. microcarpum & 36 & - & - & - & 0.5 & 32 & - & 12 & - & - \\
\hline G. nanolumem & - & - & 0.2 & - & 2.3 & 637 & - & 170 & 0.5 & 8 \\
\hline G. occultum & 0.2 & - & 0.5 & - & 0.2 & - & 1.3 & - & - & - \\
\hline G. reticulatum & - & - & 1.7 & - & 600.9 & 841 & 0.7 & 181 & 2691.0 & 16 \\
\hline G. sinuosum & - & - & - & - & - & 61 & - & - & - & - \\
\hline G. sp1 & - & - & - & 180 & - & - & - & 235 & - & 56 \\
\hline G. sp2 & - & - & - & - & - & 70 & - & 110 & - & 39 \\
\hline G. sp4 & - & - & 1.7 & - & 0.2 & - & - & - & 0.2 & - \\
\hline G. sp5 & - & - & - & - & - & - & - & 36 & - & - \\
\hline G. sp6 & - & - & 6.9 & - & - & - & 0.7 & 42 & 0.5 & 26 \\
\hline G. sp7 & - & - & 9.1 & 7 & 191.5 & 250 & 2.3 & - & 27.5 & - \\
\hline
\end{tabular}

In the samples taken from the bioassay, some species presented a higher density of spores such as Claroideoglomus claroideum, G. formosanum, G. clavisporum, G. glomerulatum, G. microcarpum, G. nanolumem, among others.

\section{DISCUSSION}

In an ecological studies about AMF diversity, it is important to obtain as much information as possible. As might be expected, simple spore extraction from 
samples taken from the field may not be sufficient. The bioassay technique used to assess AMF communities, despite some disadvantages, represents an additional tool for the understanding of AMF community structure. With this technique as noted above, it has been shown that the number of species recovered was much higher than the number of species extracted directly from field samples (Figure 1).

The richness of species did not differ markedly between the age of the forest. The number of species recovered from different periods of forest regeneration was similar to that of the native forest, probably due to the fact that the top soil, previously removed, was returned to the area of bauxite mining (Figure 1). Nevertheless, in the early years of the revegetation, the total number of species was high because the number of rare ones was also high due to the high dominance of G. macrocarpum (Table 4). However, under older communities, this high dominance of G. macrocarpum decreased with an increased number of individuals from other AMF species. For this reason, Shannon`s diversity increased while the number of species did not. The number of species did not change but the community structure of AMF did with the age of revegetation (Figure 2).

Husband et al. (2002) investigating the diversity and distribution of AMF in the tropical forest also found AM fungal types that were dominant in the newly germinated seedlings but were almost entirely replaced by previously rare types. This study found 47 species of AMF in all the areas and 76.6\% (36) occur in the last stages of succession (12 and 16 years old), corroborating with Sousa et al. (2014) that observed that areas with late stage of succession had higher species richness suggesting that the vegetation causes a positive effect on the fungical community.

Acaulospora species are usually founded in greater number during the earlier stages of the revegetation (Table 1). This suggests that these species are more adaptable to early stages of revegetation. Entrophospora, Kuklospora and Gigasporales species are mainly recovered with the bioassay technique probably because these genera produce spores in dry season (Tables 2 and 3 ). In this study samples were taken in the wet season. The order Glomerales showed better adaptation to soils recovering after bauxite mining on the basis of its larger number of species and higher spore density
(Table 4). Glomus macrocarpum was the only species found in all areas. This species was found with great abundance at the beginning of the revegetation, but also under native forest.

\section{CONCLUSION}

These results show the relevance of the bioassay technique, along with the direct sampling from the field to assess not only the diversity but also the structure of AMF community. It has been shown that the number of AMF species may not change in forest age but the structure of its community might and in the earlier stages of the revegetation there were few dominant species with a higher number of rare ones.

\section{ACKNOWLEDGEMENTS}

To the Programa de Pós-GRADUAÇÃO em Ciência do Solo of the UFRRJ support in field missions.

\section{SUBMISSION STATUS}

Received: 20 aug., 2017

Accepted: 26 oct., 2017

\section{CORRESPONDENCE TO}

\section{Ricardo Luiz Louro Berbara}

Departamento de Solos, Universidade Federal Rural do Rio de Janeiro - UFRRJ, Km 7, BR 465, CEP 23890-000, Seropédica, RJ, Brasil

e-mail: berbara@ufrrj.br

FINANCIAL SUPPORT

FAPERJ - CNE; CNPq - Universal.

\section{REFERENCES}

Błaszkowski J. Glomeromycota. Kraków: W. Szafer Institute of Botany, Polish Academy of Sciences; 2012.

Brundrett MC, Abbott LK, Jasper DA. Glomalean mycorrhizal fungi from tropical Australia. I. Comparison of the effectiveness and specificity of different isolation procedures. Mycorrhiza 1999; 8(6): 305-314. http://dx.doi. org/10.1007/s005720050251. 
Brundrett MC. Mycorrhizal associations and other means of nutrition of vascular plants: understanding the global diversity of host plants by resolving conflicting information and developing reliable means of diagnosis. Plant and Soil 2009; 320(1-2): 37-77. http://dx.doi.org/10.1007/ s11104-008-9877-9.

Caproni AL, Franco AA, Berbara RL, Trufem SB, Granha JR, Monteiro AB. Ocorrência de fungos micorrízicos arbusculares em áreas reflorestadas remanescentes da mineração de bauxita em Porto Trombetas, PA. Pesquisa Agropecuária Brasileira 2003; 38(12): 1409-1418.

Daniels BA, Skipper HD. Methods for the recovery and quantitative estimation of propagules from soil. In: Schenck NC, editor. Methods and principles of mycorrhizal research. St. Louis: American Phytopatological Society; 1982. p. 29-35.

Gerdemann JW, Nicolson TH. Spores of mycorrhizal endogone species extracted from soil by wet-sieving and decanting. Transactions of the British Mycological Society 1963; 46(2): 235-244. http://dx.doi.org/10.1016/ S0007-1536(63)80079-0.

Goto BT, Silva GA, Assis DMA, Silva DKA, Souza RG, Ferreira ACA et al. Intraornatosporaceae (Gigasporales), a new family with two new genera and two new species. Mycotaxon 2012; 119(1): 117-132. http://dx.doi. org/10.5248/119.117.

Hendrix W, Guo BZ, An Z-Q. Divergence of mycorrhizal fungal comunities in crop production systems. Plant and Soil 1995; 170(1): 131-140. http://dx.doi.org/10.1007/ BF02183061.

Husband R, Herre EA, Young JP. Temporal variation in the arbuscular mycorrhizal communities colonizing seedling in a tropical forest. FEMS Microbiology Ecology 2002; 42(1): 131-136. http://dx.doi.org/10.1111/j.1574-6941.2002. tb01002.x. PMid:19709272.

International Culture Collection of (Vesicular) Arbuscular Mycorrhizal Fungi - INVAM. International culture collection of arbuscular and VA Mycorrhizal Fungi [online]. Morgantown: West Virginia University; 2000. [cited 2000 July 05]. Available from: http://invam.wvu.edu</eref $>$.

Jasper DA, Abbott LK, Robson AD. The effect of soil disturbance on vesicular arbuscular mycorrhizal fungi, in soils from different vegetation types. The New Phytologist 1991; 118(3): 471-476. http://dx.doi. org/10.1111/j.1469-8137.1991.tb00029.x.

Landis FC, Gargas A, Givnish TJ. Relationships among arbuscular mycorrhizal fungi, vascular plants and environmental conditions in Oak Savannas. The New Phytologist 2004; 164(3): 493-504. http://dx.doi. org/10.1111/j.1469-8137.2004.01202.x.

Melloni R, Siqueira JO, Moreira FMS. Fungos micorrízicos arbusculares em solos de área de mineração de bauxita em reabilitação. Pesquisa Agropecuária Brasileira 2003;
38(2): 267-276. http://dx.doi.org/10.1590/S0100204X2003000200014

Mergulhão ACES, Burity HA, Goto BT, Maia LC. Diversity of arbuscular mycorrhizal fungi in a gypsum mining impacted semiarid area. Acta Botanica Brasílica 2010; 24(4): 1052-1061. http://dx.doi.org/10.1590/S010233062010000400020 .

Oehl F, Sieverding E, Palenzuela J, Ineichen K, Alves da Silva G. Advances in Glomeromycota taxonomy and classification. IMA Fungus 2011; 2(2): 191-199. http://dx.doi. org/10.5598/imafungus.2011.02.02.10. PMid:22679604.

Schenck NC, Perez Y. A manual of identification of vesicular-arbuscular mycorrhizal fungi. 2nd ed. Florida: University of Florida; 1988. 241 p.

Sieverding E, Friedrichsen J, Suden W. Vesicular-arbuscular mycorrhiza management in tropical agrosystems. Eschborn: Sonderpublikation der GTZ; 1991.

Simpson D, Daft MJ. Spore production and mycorrhizal development in various tropical crop host infected with Glomus clarum. Plant and Soil 1990; 121(2): 171-178. http://dx.doi.org/10.1007/BF00012309.

Smith SE, Read DJ. Mycorrhizal symbiosis. 3rd ed. London: Academic Press; 2008.

Sousa CS, Menezes RSC, Sampaio EVSB, Lima FS, Maia LC, Oehl F. Arbuscular mycorrhizal fungi in successional stages of Caatinga in the semi-arid region of Brazil. Ciência Florestal 2014; 24(1): 137-148. http://dx.doi. org/10.5902/1980509813331.

Tommerup IC. Methods for the study of the population biology of vesicular-arbuscular mycorrhizal fungi. In: Norris JR, Read DJ, Varma AK, editors. Techniques for the study of mycorrhiza. London: Academic Press; 1994. p. 483-512. (Methods in Microbiology; no. 24).

Turrini A, Sbrana C, Strani P, Pezzarossa B, Risaliti R, Giovannetti M. Arbuscular mycorrhizal fungi of a Mediterranean island (Pianosa), whitin a UNESCO Biosphere Reserve. Biology and Fertility of Soils 2010; 46(5): 511-520. http://dx.doi.org/10.1007/s00374-010-0446-z.

van der Heijden MGA, Bardgett RD, van Straalen NM. The unseen majority: soil microbes as drivers of plant diversity and productivity in terrestrial ecosystems. Ecology Letters 2008; 11(3): 296-310. http://dx.doi.org/10.1111/j.14610248.2007.01139.x. PMid:18047587.

van der Heijden MGA, Martin FM, Selosse M-A, Sanders IA. Mycorrhizal ecology and evolution: the past, the present, and the future. The New Phytologist 2015; 205(4): 1406-1423. http://dx.doi.org/10.1111/nph.13288. PMid:25639293.

Zangaro W, Bononi VLR, Trufen SFB. Mycorrhizal dependency, inoculum potential and habitat preference of native woody species in south Brazil. Journal of Tropical Ecology 2000; 16(4): 603-622. http://dx.doi.org/10.1017/ S0266467400001607. 